\title{
PELATIHAN PENULISAN PEMBUATAN PROPOSAL PENELITIAN TINDAKAN KELAS
}

\author{
Arie Purwa Kusuma ${ }^{1)}$, Nurina Kurniasari Rahmawati' ${ }^{2}$, \\ Abdul Hakim Ma'ruf', Andi Ahmad ${ }^{4}$ \\ ${ }^{1,2,3,4)}$ Pendidikan Matematika STKIP Kusuma Negara Jakarta \\ E-mail: Arie_pk@stkipkusumanegara.ac.id
}

\begin{abstract}
The Purpose of Implementing Class Action Research (PTK) is an effort to improve the quality of learning which is one of the demands of competence, at this time research has become a problem that is difficult for teachers to implement. Their main difficulty is because the teachers do not know and understand about PTK, so this results in a lack of motivation to conduct research. The training was held in SMP N 2 Candimulyo, in the pelatiahan activity it was aimed at assisting teachers in writing PTK proposals, in the implementation of using methods of material presentation in theory, discussion and practice of making research proposals. The technical implementation is the preparation of proposals which include clinical preparation of proposals, conveying several learning models that will be used in research, assistance in conducting research and preparing the final report. The results achieved in this activity, the teachers increased their understanding of PTK so that the knowledge gained by the teachers could be used as a process of improving learning in the classroom.
\end{abstract}

Keywords: Class Action Research, Learning Model, Teacher.

\begin{abstract}
Abstrak
Tujuan Melaksanakan kegiatan Penelitian tindakan kelas (PTK) adalah upaya untuk meningkatkan kualitas pembelajaran yang menjadi salah satu tuntutan kompetensi, pada saat ini penelitian menjadi masalah yang sulit dilaksanakan oleh para guru. Kesulitan utama mereka karena guruguru kurang mengetahui dan memahami mengenai PTK, sehingga hal tersebut mengakibatkan kurangnya motivasi untuk melakukan penelitian. Pelatihan ini dilaksanakan di SMP N 2 Candimulyo, pada kegiatan pelatihan ini bertujuan untuk mendampingi guru dalam penulisan proposal PTK, kegiatan tersebut merupakan kegiatan pengabdian kepada masyarakat yang di laksanakan oleh STKIP Kusuma Negara, dalam pelaksanaannya menggunakan metode pemamparan materi secara teori, diskusi dan latihan pembuatan proposal penelitian. Teknis pelaksanaanya adalah penyusunan proposal yang meliputi klinis penyusunan proposal, menyampaikan beberapa model pembelajaran yang akan digunakan dalam penelitian, pendampingan pelaksanaan penelitian dan penyusunan akhir laporan. Hasil yang dicapai dalam kegiatan ini, para guru bertambah pemahamannya pada PTK sehingga ilu yang di dapatkan oleh para guru dapat digunakan sebagai proses perbaikan pebelajaran di kelas.
\end{abstract}

Kata kunci: Penelitian Tindakan Kelas, Model Pembelajaran, Guru.

\section{PENDAHULUAN}

Guru dikatakan profesional apabila memiliki empat kompetensi yaitu kompetensi pedagogik, kompetensi kepribadian, kompetensi sosial, dan kompetensi profesional yang diperoleh melalui pendidikanprofesi. Di dalam Undang-Undang RI Nomor 20 Tahun 2003 tentang Sistern
Pendidikan Nasional, Undang-undang RI Nomor 14 Tahun 2005 tentang guru dan Dosen dinyatakan bahwa guru adalah pendidik professional. Dalam materi pelatihan Membimbing Guru dalam PTK yang diselenggarakan oleh Direktorat Tenaga Kependidikan, diuraikan bahwa di dalam pasal 14 dan 15 Undang-undang tersebut 
dtnyatakan bahwa guru berhak memperoleh penghasilan di atas kebutuhan hidup minimum dan jaminan kesejahteraan sosial, meliputi gaji pokok, tunjangan yang melekatpada gaji, serta penghasilan lain berupa tunjangan profesitunjangan fungsional, tunjangan khusus, dan maslahat tambahan yang terkait dengan tugasnya sebagai guru yang ditetapkan dengan prinsip penghargaan atas dasar prestasi.

Untuk memperoleh hal tersebut harus di ikuti dengan peningkatan serta mitmen dalam bekerja secara profesional. Salah satu cara untuk meningkatan profesionalisme guru adalah dengan penelitian tindakan kelas. Selain untuk meningkatkan kompetensi guru sesuai dengan Peraturan Menteri Negara Pendayagunaan Aparatur Negara dan Birokrasi Reformasi (Permen PAN) Nomor 16 Tahun 2009 Tentang Jabatan Fungsional Guru menjelaskan bahwa syarat kenaikan pangkat bagi guru menjadi golongan III-c ke atas, wajib membuat publikasi ilmiah dan atau karya inovatif. Publikasi ilmiah meliputi hasil penelitian atau gagasan inovatif pada bidang pendidikan formal; dan publikasi buku teks pelajaran, buku pengayaan, dan pedoman Guru. Sedangkan karya Inovatif meliputi menemukan teknologi tepat guna; menemukan/menciptakan karya seni; membuat/memodifikasi alat pelajaran/peraga/praktikum; dan mengikuti pengembangan penyusunan standar, pedoman, soal dan sejenisnya.

Salah satu karya tulis ilmiah guru berasal dari hasil Penelitian Tindakan Kelas (PTK) yang diangkat dari permasalahan yang dihadapinya dalam melaksanakan pembelajaran di kelas melalui penerapan berbagai metode, pendekatan, strategi dan model-model pembelajaran. Oleh sebab itu penguasaan berbagai metode, pendekatan, strategi dan model-model pembelajaran memiliki keterkaitan yang tidak dapat dipisahkan dengan kegiatan pengembangan profesi guru (Widayati dan Haffis, 2012). Kemampuan guru untuk meneliti akan meningkatkan kinerja dalam profesinya sebagai pendidik. Beberapa kriteria yang perlu dijadikan pegangan guru seperti yang disarankan Hopkins (1993) antara lain : (1) tugas utama guru adalah mengajar, jangan sampai kegiatan penelitian mengganggu tugas utama ini, (2) metode pengumpulan data dipilih cara yang efisien dan relevan dengan kebutuhan sehingga tidak memakan banyak waktu, (3) telah menguasai langkahlangkah PTK sehingga mampu menyusun hipotesis kerja dan strategi pembelajaran yang akan dikembangkan sesuai kondisi kelas dengan percaya diri, (4) masalah penelitian sesuai dengan bidang tugas guru.

Berdasarkan dari hasil observasi di SMP N 2 Candimulyo ditemukan masih banyak kendala bagi guru untuk melaksanakan penelitian tidakan kelas, sehingga berdampak pada rendahnya motivasi para guru untuk melaksanakan PTK. Para guru masih sangat kurang berpengalaman dalam pelaksanaan PTK, para guru belum memahami cara merancang PTK dalam suatu pelajaran, guru belum memahami strategi, model, metode dan pendekatan pembelajaran yang digunakan setip hari-hari. Mereka juga belum memahami tentang pengambilan data statistik yang tepat dan efisien, cara menganalisi data interpretasi hasil dan penyimpulan hasil pelaksanaan PTK.

Berdasarkan beberapa kendala tersebut, maka diperlukan suatu upaya untuk mengatasi permasalahan tersebut. Oleh karena itu Program Studi Pendidikan Matematika STKIP Kusuma Negara melakakuan kegiatan Pengabdian dengan melaksanakan Pelatihan Penulisan Pembuatan Proposal Penelitian Tindakan Kelas.

\section{METODE PELAKSANAAN}

Sasaran kegiatan pengabdian masyarakt ini adalah guru SMP $\mathrm{N} 2$ Candimulyo, Kabupaten Magelang. Dengan jumlah 20 Orang. Tahapan kegiatan yang dilakukan dalam penelitian tindakan kelas adalah. Pemberian materi mengenai sistematika penyusnan proposal PTK, model, Metode, Strategi dan pendekatan yang bisa digunakan dalam pembelajaran untuk mendukung PTK, materi yang berkaitan 
dengan PTK, pembuatan proposal dan pendampingan pelaksanaan PTK sampai laporan akhir.

1. Tahap perencanaan

Tahan melaksanakan observasi untuk mencari informasi tetang masalahmasalah yang di hadapi dalam kegiatan pembelajaran disekolah.

2. Tahap Kegiatan

Pada tahap ini para pemateri memberikan teori tentang sistematis penyusunan proposal PTK, antara lain mengenai penyusunan latar belakang, identifikasi masalah, rumusan masalah, batasan masalah dan manfaat penelitian. Membentuk instrument penelitian, proses pelaksanaan tindakan, analisis dan refleksi. Pada kegiatan inijuga disampaikan mengenai indikator kreteria keberhasilan penelitian.

3. Penyusunan Proposal

Pada kegiatan ini para peserta diberikan waktu untuk membuat proposal, dengan membentuk beberapa kelompok penelitian. Kelompok tersebut nantinya akan dibimbing oleh para pemateri supaya lebh efisien dan efektif. Para peserta pelatihan diberikan kesempatan untuk tanya jawab dengan pemateri, selain itu mereka juga melakukan diskusi dengan teman sekelompok untuk membantu mengatasi kesulitan-kesulitan yang mereka hadapai dalam penyusunan. Setelah mereka menyelesaiakan proposal yang masih berbentuk draf, kemudian dilakukan presentasi setiap kelompoknya dan mendapatkan masukan dari kelompok yang lain.

4. Tahapan Refleksi kegiatan Penutup Berdasarkan hasil pelaksanaan tersebut, diakhir kegiatan dilakukan refleksi untuk mengetahui hasil dari pelatihan. Draf proposal PTK yang sudah selesai direvisi nanti nya akan dikirim ke pemateri melalui email untuk di cek ulang. Kemudian akan ditulis komentar kelebihan dan kekurangan dari hasil penulisan. Selanjutnya hasil penelitian dapat digunakan oleh para guru untuk memperbaiki proses pembelajaran di kelas, recomendasi model pembelajaran yang lebih baik.

\section{HASIL DAN PEMBAHASAN}

Setelah mengikuti pelatihan ini dapat mrnghasilkan draf proposal penelitian tindakan kelas (PTK) dari masing-masing guru yang nantinya bisa di tindak lanjuti untuk melakukan PTK. Dalam sesi pemberian materi tentang penyusunan proposal PTK terjadi komunikasi yang baik dimana peserta sangat aktif bertanya kepada pemateri sehingga suasa diskusinya menjadi sangat menarik dan interaktif. Kegiatan berlanjut ketika pembentukanbeberapa kelompok diskusi berjalan lebih interaktif karena terjadi diskusi antar kelompok dan dilanjutkan dengan presentasi setiap kelompok yang dikomentari kelompok yang lain. dari 20 peserta terdapat 5 kelompok dimana masing-masing kelompok terdiri dari 4 anggota dan menghasilkan 5 draf proposal.

Dengan variasi judul proposal yang berbeda seperti model yang diterapkan dan materi yang diajarkan oleh peserta memperlihatkan suatu usaha dimana pesertamemperlihatkan kemampuan yang sangat sunguh-sungguh dalam upaya ntuk memecahkan sebuah masalah ketika dikelas dengan melakukan penelitian. jika penelitian proposal dari BAB I sampai dengan BAB III PTK sudah melaksanakan $65 \%$ penelitiannya, selebihnya $35 \%$ adalah pelaksanaan pengumpulan data dan analisis data, pembahasan kesimpulan dan saran. Rangkaian terakhir Pelatiahan ini adalah pendampingan penyusunan laporan akhir dan kesimpulan pada hasil penelitian. Hasil penelitian diharapkan dapat menambah kemampuan para guru untuk memperbaiki mutu pembelajaran. Selain itu untuk mengembangkan inovasi pemlejaran sehingga kegiatan pemelajaran lebih menarik dan interaktif.

Di Tahap terkahir dilakukan monitoring dan evaluasi dengan tujuan untuk mendeteksi dan mengevaluasi keseluruhan kegiatan pelatihan sehingga dapat diketahui permasalahan dan kendala yag muncul. Dari 
hasil evaluasi kegiatan pelatihan sangat baik dan terjadi diskuis yang menarik, bahkan beberapa peserta memberikan masukan dengan mengatakan dengan adanya pelatihan ini sangan bermanfaat bagi pengembangan dan peningkatan profesionalitas guru. Adapaun kendala dilapangan yang teridentifikasi adalah hal-hal teknis, antara lain jadwal kegiatan yang menyesuaikan jadwal mengajar guru dan dana yang terbatas.

\section{KESIMPULAN}

Berdasarkan pembahasan di atas, dapat disimpulkan dari hasil kegiatan pelatihan Penelitian Tindakan Kelas (PTK) kali ini adalah guru peserta kegiatan menjadi lebih memahami dan terampil mengenai PTK, dari penyusunan proposal sampai pelaksanan penelitian dan laporan. Guru mengenal lebih banyak tentang model-model pembelajran yang dapat digunakan dalam pembelajaran dikelas. Perlu pendampingan lebih lanjut secara terus menerus tentang penyusunan proposal dan laporan penelitian tindakan kelas untuk meningkatkan profesionalisme guru. Hasil kegiatan ini dapat dijadikan acuan dan bahan kajian lebih lanjut bagi LPTK dan para Dosen untuk melaksanakan kegiatan pengabdian masyarakat.

\section{REFERENSI}

A.A. Gde Somatanaya, Linda Herawati, Setya Wahyuningsih.(2017) Pelatihan Penelitian Tindakan Kelas (PTK) Bagi Peningkatan Karier Guru-Guru Sekolah Dasar Kota Tasikmalaya. Jurnal Pengabdian Siliwangi. Volume 3 No. 1.169 - 175

Djam an Satori dkk, (2003). Profesi Keguruan 1. Universitas Terbuka : Jakarta

Depdiknas. (2005). Undang - Undang Nomor 14 Tahun 2005 Tentang Guru dan Dosen.

Departemen Pendidikan Nasional. (2003). Undang-undang No. 20 Tahun 2003 tentang Sistem Pendidikan Nasional. Jakarta.

Hunaepi.(2016) Pelatihan Penelitian Tindakan Kelas (PTK) dan Teknik Penulisan Karya Ilmiah Bagi Guru di MTs. NW Mertaknao. Jurnal Pengabdiankepada Masyarakat IKIP Mataram LumbungInovasi. Volume 1 No. $1.38-40$

Laba Jayanta, I. N., Rati, N. ., Diputra, K. S., \& Wibawa, I. M. C. (2017). Pelatihan Penyusunan Proposal Penelitian Tindakan Kelas Bagi Guru-Guru Sd. Jurnal Widya Laksana, 6(1), 1-7.

Isa Ansori, Purnomo.(2017) Pelatihan Tentang Penyusunan Proposal dan Laporan Penelitian Tindakan Kelas pada Guru Sekolah Dasar Gugus Ki Hajar Dewantoro Dabin I Kecamatan Tugu Kota Semrang. Jurnal Kreatif: Jurnal Kependidikan Dasar. Volume 7 No. 2. 130-142.

PJana, B. Pamungkas. (2018). Pelatihan Penelitian Tindakan Kelas Bagi Guru SD Negeri Guwosari . Jurnal Abdimas Dewantara, Vol 1, No. 1, 39-46.

Slameto, (2011). Penyusunan Proposal dan Hasil Penelitian Tindakan Kelas.Salatiga: Widya Sari Press

Slameto.(2015). Penyusunan Proposal Penelitian Tindakan Kelas. Jurnal Scholaria: Jurnal Pendidikan dan Kebudayaan. Volume 5 No. 2. 60-69.

Soesatyo, Y., Subroto, W.T., Sakti, N. C., Edwar, M., \& Trisnawati, N.(2017) Pelatihan Penulisan Proposal Penelitian Tindakan Kelas (PTK) Bagi Guru Ekonomi Kabupaten Sidoarjo. Jurnal Pemberdayaan Masyarakat Madani (JPMM). Volume 1 No. 2. 164-178.

Wiganda, S. (2014). Pelatihan Penelitian Tindakan Kelas Bagi Guru-Guru SeJakarta Timur. Jurnal Sarwahita, 11 No. 1(1), 1-7. 